Volume 7 Issue 2, June 2020

Nationally Accredited Journal,

Decree No. B/4130/E5/E5.2.1/2019

\title{
Analysis of Judicial Application of Criminal Penalty Against Notary / Land Deed Officials Conducting Making Crime of the Fake Authentic Deed in State Court of Semarang
}

\author{
Mohammad Barkah Arrohim¹, Haris Wahyu Sunarno ${ }^{2}$ and Sri Endah \\ Wahyuningsih ${ }^{3}$
}

\begin{abstract}
The purpose of this study was to: 1) analyze the application of criminal penalty against Notary / PPAT in the crime of counterfeiting deed on the Case In State Court of Semarang. 2) Analyze the legal consequences of the Notary / PPAT penalized following criminal of fake deed as object case in court on a lawsuit in State Court of Semarang. The approach in this research is normative juridical that while the data used in this research primary data, secondary data and data that can support tertiary study, which was then analyzed by descriptive analytical method.

Based on the results of data analysis concluded that: 1) The application of criminal law to the Notary / PPAT in the crime of falsification of the authentic deed in case Criminal judges are viewed from the indictment, formally defendant has fulfilled the elements formulation in forgery and materially to hear and see information from the defendant, the witnesses and the evidence presented in the trial and have sufficient minimum of two (2) valid evidence, the defendant was found guilty and convincingly to have committed the crime of falsification of the authentic Article 264 of the criminal Code in conjunction with Article 55 (1) e of the criminal Code that is alleged to defendant ,2) The legal consequences of the Notary / PPAT sanctioned criminal in the crime of counterfeiting authentic deed along with the deed that made the object of a case in court on the case Criminal defendant Notary / PPAT sentenced to prison with a prison sentence and All certificates issued by the defendant Notary / PPAT canceled in favor law.

Keywords: Criminal Penalty; Notary / PPAT; Authentic Deed.
\end{abstract}

\section{Introduction}

Land is one of the most important elements in life and human progress, society and nation. From process to sustain life until terminated by their death, the land remains the most important element in the life of society. Not denying that the land is the source of people's lives. The importance of the land and the people's lives here in the land become a valuable commodity is created professions related to land ownership is a notary

Notary is an honorable profession and always concerned with morals and ethics when performing his respective duties. When performing his respective duties, notary public / PPAT cling and uphold the dignity of his profession as a respectable position. Because adherence to the notary profession ethics is referred to as a noble profession (officium nobile). ${ }^{4}$

Understanding Notary, contained in Article 1 (1) of Act No. 2 of 2014 concerning Notary stating "the notary is a public official who is authorized to make the authentic

\footnotetext{
${ }^{1}$ Student Master of Notary Program (Mkn) Sultan Agung Islamic University, Semarang, Email: mohammadbarkaharrohim@gmail.com

${ }^{2}$ Student of Master of Law Program, Faculty of Law Universitas Islam Sultan Agung email hariswahyu86@gmail.com

${ }^{3}$ Lecturer, Faculty of Law, Sultan Agung Islamic University, Semarang

${ }^{4}$ Abdul Ghofur Anshori, 2009, Lembaga Kenotariatan Indonesia, Yogyakarta: UII Press, p. 6
} 
deed and have other authorities referred to in this Act or pursuant to an Act more.

Authentic deed made theoretically is a letter or a deed from the outset deliberately meant that since the beginning of the letter made the goal is to future proof in case of disputes.

The act of making a false letter is the act of making a previous letter which not appear, that some or all of the false contents. Letters resulting from these actions is called the letter a fake. While the act of falsifying, is legal form any action aimed at an existing letter, by removing, changing or replacing one letter so different from the original letter. ${ }^{5}$

Counterfeiting is a crime that is stipulated in Chapter XII of Book II of the Criminal Code, which in the book is included that included forgery are in the form of writings alone, including the falsification of signatures set forth in article 263 KUHP and the Article 276 of the Criminal Code.

Crime is often the case with regard to Article 263 of the Criminal Code (making false or forged letter); and Article 264 (falsifying deeds authentic) and article 266 of the Criminal Code (told to enter false information into an authentic deed).

Examples of cases found among others Notary DNE demanded prison for the alleged forgery of certificates are authentic and the appropriation of land covering an area of 23 hectares in Pranti, Sedati sub district, Sidoarjo.

Based on the background of the problems mentioned above regarding property rights trumped by a person, the author interested in conducting research titled " Analysis of Judicial Application of Criminal Penalty Against Notary / Land Deed Officials Conducting Making Crime of the Fake Authentic Deed in State Court of Semarang"

\section{Research methods}

The method of research is a normative, so it can be used more than one approach to research. ${ }^{6}$ While collecting materials research carried out by studying the data that have a relationship with the problems, which are obtained from secondary data supported by the primary data in the form of interviews with informants, secondary data is data obtained from library materials. ${ }^{7}$

\section{Results and Discussion}

\subsection{The Application of Criminal Penalty Against Notary / Land Deed Officials Conducting Making Crime of the Fake Authentic Deed in State Court of Semarang}

Basic legal reasoning used by the judge in imposing criminal decisions against Notaries are referring to the provisions of Article 266 paragraph (1) of the Criminal Code which states the elements in terms of this article are met by means of the defendant together (participating) to plot a deed authentic as if the contents match the reality / truth.

The deed is done deliberately with the intention of such certificates can be used to acquire land area which is not in accordance with the agreement / bond selling as harmful to others as in the Article 266 paragraph (1) of the Criminal Code.

The imposition of penalty as a legal responsibility of the Notary in their profession are classified in two (2) forms: (1) The responsibility of Civil Law that if a Notary to make

\footnotetext{
${ }^{5}$ Adami Chazawi, 2005, Kejahatan terhadap Pemalsuan, Jakarta: Pt. RajaGrafindo Persada, p. 11

${ }^{6}$ Johnny Ibrahim, 2012, Teori dan Metodologi Penelitian Normatif, Malang: Bayumedia Publising, Pg. 300.

${ }^{7}$ Soerjono Soekanto, 2009, Penghantar Penelitian Hukum, Jakarta: UI-Press, p. 51
} 
Volume 7 Issue 2, June 2020

Nationally Accredited Journal,

Decree No. B/4130/E5/E5.2.1/2019

mistakes because of broken promises as set forth in Article 1234 Civil Law or legal violation as provided in Article 1365 Civil Code; (2) The responsibility of the Criminal Law when the notary are legal actions that are prohibited by law or made a mistake / tort either because of deliberate or negligent causing losses of others. In particular the rule of law, as well as administrative penalty, also may be subject to criminal penalty (cumulatively) which is comdenatoir (punitive) or punish. Therefore UUJN not regulate criminal penalty for violating Notary UUJN, so that in case of violations of the criminal law against acts of Notary subject and apply the general criminal set out in the Code of Penal (Penal Code). If the Notaries perform a deed that made aberrations that cause a criminal case, then Notary criminally accountable for what he has done that.

Procedures for application of criminal penalty in the form of court decisions that have a legal effect the verdict to punish the Notary to undergo a certain criminal as the aforementioned decision, demonstrate accountability to criminal against notaries who committed an unlawful act may be subject to criminal penalty in the form of imprisonment, as set in the draft of Criminal Law (Penal Code). In penalty against the Notary must fulfill formulation that acts prohibited by law, any loss arising from the deed, and the deed should be against the law of both formal and material. The application of Article 266 (1) of the Criminal Code, there is no formula regarding asked to enter fake information, but it is known and is implicit from the element / phrase 'in an authentic deed ", which implies that the person is the creator of an authentic deed. This means referred to in this decision is a Notary is one of the public official authorized to make an authentic deed. Notary in making authentic deed is to meet the demand of people / persons are facing, so the person who asked this question that were sent to enter false information. On the other hand, there are different opinions stating that the person facing to the Notary supply of information for inclusion in an authentic deed, but the information given is untrue. In this case the Notary not be falsified as Article 266 paragraph (1) of the Criminal Code, for someone to Notary and provide information about things that are contrary to the truth. So here it is only a deed Notary and included in deed notified. It is therefore not possible in committing persuade (Article 55 paragraph (1) to 2 of the Criminal Code) or give help (Article 56 of Penal Code) because there was no crime committed Notary. Notaries do not know that the particular entered in the certificate is incorrect. It is therefore not possible in committing persuade (Article 55 paragraph (1) to 2 of the Criminal Code) or give help (Article 56 of Penal Code) because there was no crime committed Notary. Notaries do not know that the particulars entered in the certificate is incorrect. It is therefore not possible in committing persuade (Article 55 paragraph (1) to 2 of the Criminal Code) or give help (Article 56 Penal Code) because there was no crime committed Notary. Notaries do not know that the particulars entered in the certificate is incorrect. ${ }^{8}$ Based on the criminal case No. 1099 / k / pid / 2010 is based on the evidence revealed at the hearing that witness statements, letters and statements of experts. Judge State Court until the decision declaring that the defendant proven legally and convincingly the defendant guilty of the crime of entering and participating did knowingly entering false information in an authentic deed on a matter that the truth must be stated deed with the intention to wear and sent another deed wear it as if the information is in accordance with the truth. As charged in the first indictment of violating Article 23 paragraph 1 of the Criminal Code in conjunction Article 55 paragraph 1 point 1 of the

8 H Moch. Anwar, 1982, Hukum Pidana Bagian Khusus (Penal Code Book II) Volume 1, Bandung: Alumni 
Criminal Code.

Based on consideration of the judge in this case was appropriate because it had sentenced the convicted person violating the provisions of Article 264 of the Criminal Code in conjunction with Article 55 of the Criminal Code because it has been proven to commit a criminal offense as an authentic deed. As people can lose confidence in the notary deeds notary who forged an authentic deed. The authentic deed is the strongest evidence in civil evidence.

\subsection{The Legal Consequences of the Notary / Land Deed Officials Conducting Making Crime of the Fake Authentic Deed in State Court of Semarang}

As a result of the law against counterfeiting authentic deed made by the notary is where the notary dragged in the case of falsification of certificates which became the intellectual actor or notary participating party to forgery that can be categorized in deed the offense is then legally can not be tolerated not only by criminal provisions alone, but also by the Rules and Regulations of the Civil Code BW Notary Law (UUJN). As for some of the imposition of penalty if the notary proven to have committed an authentic fake deed then the penalty that can be imposed on notaries who have violated the law, namely:

- According to Act No. 30 of 2004 concerning Notary, namely the imposition of penalty Administrative or Notary Code On Administrative instrument of law enforcement in Notary Law, covering preventive measures (Supervision) and repressive measures (application of penalty). Preventive measures carried out through periodic inspection protocol notary and possible violation of code of conduct in the execution of the notary office. While repressive action is carried out through penalty by:

- Regional Supervisory Council, in the form of verbal reprimand and written warning and is entitled to propose to the Supervisory Council Center of suspension (three) 3 months up to (six) 6 months and a dishonorable discharge.

- Central Supervisory Council, in the form of a suspension and is entitled to propose to the minister in the form of dishonorable discharge.

- Minister, in the form of dishonorable discharge and a dishonorable discharge.

- According to BW in the Book of the of Civil Law, deeds counterfeiting authentic deed performed by a notary, as well as the elements of Deeds Against the law in accordance with the elements contained in article 1365 of the Code of Civil Code can be broken down and fulfilled in order for an it could be categorized as an act of misconduct.

According to the Code of Criminal Occurrence of criminal prosecution against the notary by deed made by or in the presence of a notary public as part of the implementation of the duties of office or authority of the notary, without regard to the rules of law relating to the procedures for deed and only under the provisions of the draft of Penal Law (penal Code) alone, suggesting the occurrence of misunderstanding or interpretation of the position of the notary while the notary deed as evidence in the civil law. Ultimum Remedium criminal penalty is that the last medication, if penalty or measures on other legal branches does not work or is not considered effective. ${ }^{9}$

For notary who committed the crime can be done for dismissal by the Minister on the grounds notary has been found guilty and subjected to imprisonment, which is set out in Ministerial Decree of 2003 concerning Notary article 21 paragraph (2) sub b is a

\footnotetext{
${ }^{9}$ Habib Adjie, Renvoi Journal, No. 10-22 March 3, 2005, p. 126.
} 
Volume 7 Issue 2, June 2020

Nationally Accredited Journal,

Decree No. B/4130/E5/E5.2.1/2019

Notary convicted directly related to his or other crimes with penalty of five (5) years in prison. The imposition of penalty in civil, administrative and even criminal to have objectives, nature, and the different procedures.

Administrative penalty and civil penalty with the goal of actions undertaken by the concerned and criminal penalty with the goal of actors (people) who did the legal action.

As a result of the Law Against Faked Deed/ Minuta By Notary. One of the requirements valid agreement contained in Article 1320 of the Civil Code which contains the agreement of the parties, acting skills, the existence of a particular case that the agreement and the existence of a lawful reason to such an agreement. If a deed led to a criminal then the terms of the agreement seen elements of the agreement contained therein. Legal experts like Sudikno Mertokusuno, Mariam Darus, and J J.Satrio agreed that elements of the agreement consists of Esensialia elements, Naturalia elements, and Aksidentalia elements. ${ }^{10}$ The first element is commonly known as a core part of the agreement, the second and third elements of so-called non-core part of the agreement. Esensialia element is the element that an absolute must have for the treaty, so that it is valid and this agreement the validity of the terms of the agreement. So the four conditions of Article 1320 of the Civil Code is an agreement Esensialia element. In other words, the nature of the agreement is Esensialia decisive nature of the agreement is created (constructieve oordeel).

Naturalia element is a common element attached to the agreement, namely the element without specifically agreed in agreement silently by itself considered to exist in the agreement. This element is an innate trait (natuur) or attached to the agreement. For example, the seller must guarantee hidden defects to the buyer. While Aksidentalia elements, means an element that must be loaded or explicitly stated in the agreement by the parties. For example, if there is a dispute, the parties have determined the selected place. To prove such a certificate is valid or invalid in this study, the presumption of legitimate use. In the provisions referred to in Article 41 UUJN-P which states that if a Notary break the provisions referred to in Article 38, Article 39 and Article 40 UUJN-P resulted in deed only has the strength of evidence as the deed under the hand, then the Notary deed only has the strength of evidence as a deed under hand, but if the parties can be authentic deed in court proceedings and resulted in the deed can be canceled and the strength of evidence as the deed under the hand will not apply continuing involvement. Because of this legal presumption relating to the irrevocable deed, an act is flawed is not competent to make a deed of Notary outward, formal, material and not in accordance with the law on Notary deed. The legal consequences of the authentic deed of Notary unlawfully causing authentic deed into a deed under the hand and the certificate can be canceled in line with the authority's theory and the concept of legal protection. As noted above in the theory of authority, Notary in making authentic deed as attribution is included in the authority, under the provisions of Article 15 paragraph (1) of the Law Amendment UUJN. The occurrence of legal consequences in the form of authentic deed into a deed under the hand and the deed was canceled due to the abuses committed by the Notary, where Notaries in running the authority has violated the provisions of the laws which resulted in losses for the parties and result in changes in the strength of evidence deed and their annulment the authentic deed by a court.

\footnotetext{
${ }^{10}$ Kartini Muljadi and Gunawan Widjaja, 2010, Perikatan yang Lahir dari Perjanjian, Jakarta: King Grafindo Persada, p. 84.
} 


\section{Closing}

\subsection{Conclusion}

- The application of criminal law to the Notary / PPAT in the crime of falsification of the authentic deed in case criminal judges are viewed from the indictment, formally defendant has fulfilled the elements formulation in forgery and materially to hear and see the information from the defendant, witnesses and evidence in trial and have sufficient minimum of two (2) valid evidence, the defendant was found guilty and convincingly of committing criminal offenses of forgery of the authentic Article 264 of the criminal Code in conjunction with Article 55 (1) e of the criminal code that is alleged to defendant

- The legal consequences of the Notary / PPAT sanctioned criminal in the crime of counterfeiting authentic deed along with the deed that made the object of a case in court on the case criminal defendant Notary / PPAT sentenced to prison with a prison sentence and All certificates issued by the defendant Notary / PPAT canceled by operation of law.

\subsection{Suggestion}

- In the Notary Act that will come also with a specific set of penalty if there Notary / PPAT committed the crime of forgery of certificates

- The willingness make the Notary / PPAT violation codes and that can be qualified in criminal acts alleged in the interest should not be obeyed.

- Reading of the deed by the Notary / PPAT should be done so that they know what the contents of the deed is in conformity with the willingness does not arise for code violations at a later date

\section{References}

[1] Abdul Ghofur Anshori, 2009, Lembaga Kenotariatan Indonesia, Yogyakarta: UII Press

[2] Adami Chazawi, 2005, Kejahatan terhadap Pemalsuan, Jakarta: Pt. RajaGrafindo Persada

[3] Johnny Ibrahim, 2012, Teori dan Metodologi Penelitian Normatif, Malang: Bayumedia Publising

[4] Soerjono Soekanto, 2009, Penghantar Penelitian Hukum, Jakarta: UI-Press.

[5] HAK H Moch. Anwar, 1982, Hukum Pidana Bagian Khusus (Penal Code Book II) Volume 1, Bandung: Alumni

[6] MA Moegni Djojodirjo, 1982, Perbuatan melawan hukum, Jakarta: pratnya paramita

[7] Kartini Muljadi and Gunawan Widjaja, 2010, Perikatan yang Lahir dari Perjanjian, Jakarta: King Grafindo Persada

[8] Habib Adjie, Renvoi Journal, No. 10-22 On March 3, 2005

[9] Book of Criminal law

[10] Code of Civil law

[11] Government Regulation No. 24 of 1997 on Land Registration

[12] Act No. 2 of 2014 on the Amendment of Act No. 30 of 2004 concerning Notary Act

[13] Code of PPAT 